\section{Evaluation of Ethyl Formate, Phosphine, and Their Combination to Disinfest Harvested Celery against Purple Scum Springtails}

\author{
Qasim Ahmed ${ }^{1,2}$, Yonglin Ren ${ }^{1,4}$, Robert Emery ${ }^{3}$, \\ James Newman ${ }^{1}$, and Manjree Agarwal ${ }^{1,4}$
}

ADDITIONAL INDEX WORDs. commodity treatment, horticultural export, insect, Hypogastrura vernalis, Apium graveolens, fumigation, phytotoxicity

SuMmARy. Export celery (Apium graveolens var. dulce) from Australia has been affected by a natural infestation of purple scum springtails (Hypogastrura vernalis). These insects live inside the celery head, contaminating fresh celery, but do not cause any visible damage. As a result, purple scum springtail-infested celery has led to rejection for export with an impact on market value for fresh produce. In this study, fumigation with ethyl formate (EF), phosphine $\left(\mathrm{PH}_{3}\right)$, and their combination on mortality of purple scum springtails in naturally infested celery was evaluated. Laboratory experiments were conducted using concentrations of 50,60, and $90 \mathrm{mg} \cdot \mathrm{L}^{-1}$ of EF for 1,2 , and 4 hours; $1,1.5,2$, and $2.5 \mathrm{mg} \cdot \mathrm{L}^{-1}$ of $\mathrm{PH}_{3}$ for 2,4 , and 6 hours; and 20,30 , and $40 \mathrm{mg} \cdot \mathrm{L}^{-1}$ of EF combined with $1 \mathrm{mg} \cdot \mathrm{L}^{-1}$ of $\mathrm{PH}_{3}$, for 2 and 4 hours at the laboratory temperature $25^{\circ} \mathrm{C}$. Complete control was achieved at 90 $\mathrm{mg} \cdot \mathrm{L}^{-1}$ of EF for 2 hours; however, phytotoxicity was observed in celery treated by $\mathrm{EF}$ at all concentrations. $\mathrm{PH}_{3}$ at $2.5 \mathrm{mg} \cdot \mathrm{L}^{-1}$ achieved $100 \%$ mortality within 6 hours, and no phytotoxicity was evident. Mortality of $100 \%$ was achieved also at 30 and $40 \mathrm{mg} \cdot \mathrm{L}^{-1} \mathrm{EF}$ combined with $1 \mathrm{mg} \cdot \mathrm{L}^{-1}$ of $\mathrm{PH}_{3}$ for 2 and 4 hours exposure time; however, phytotoxicity occurred with EF alone treatments and with the combination. From these data, we conclude that $\mathrm{PH}_{3}$ alone has potential as a fumigant for the preshipment treatment of celery infested with purple scum springtails.

$\mathrm{C}$ elery is an intensively cultivated and valuable horticultural export product from Australia. Celery is grown in most states with the main production areas in Victoria, Western Australia, and Queensland. There are cultivated areas of $\approx 235$ ha per year (Horticulture Australia, 2009). Australian celery production in 2015 was more than $60,000 \mathrm{t}$, with a value of 50.1 million Australian dollars. In 2017, celery production for export increased to 3557 t (Horticulture Innovation Australia, 2017). However, this growing market has been threatened by a natural infestation of purple scum springtails, which significantly affected market access as purple scum springtails are considered a quarantine Australian Quarantine does not allow export of plant products containing living organisms. pest in many Middle East countries.
Purple scum springtails are tiny wingless arthropods with a bulbous, rounded form. The natural densities of springtails in general in Australia range between 2000 and $30,000 \mathrm{~m}^{2}$, depending on climate, season, and habitat (Greenslade, 2007). Springtails in general feed on decaying plant material and other organisms, such as fungi, algae, and occasionally dead animals. A few species of springtails have been recorded as pests that can damage mushrooms and other crops (Greenslade and Ireson, 1986; Greenslade et al., 2014; Popenoe, 1917). Regardless of species, the preferred conditions for the growth of purple scum springtails are warmth, moisture, and high organic content (Greenslade and Kitching, 2011). Two species of springtails from the Hypogastruridae family, mushroom springtail (Ceratophysella denticulata) and purple scum springtail, have been reported on celery in Western Australia (Majer et al., 2014). These species are not considered to be primary pests, but are present because they feed on microorganisms and decaying products (Chahartaghi et al., 2005). Several species in the Hypogastruridae family can cause damage to cultivated mushrooms and are confirmed as pests of edible mushrooms in Australia, of which the most common ones are mushroom springtail, Hypogastrura manubrialis, Hypogastrura purpurescens, and purple scum springtail (Greenslade and Clift, 2004). Fumigation of the growing equipment used in a mushroom culture can prevent invading purple scum springtails and other species from damaging crops (Greenslade

\begin{tabular}{clll}
\hline $\begin{array}{l}\text { Units } \\
\text { To convert U.S. to SI, } \\
\text { multiply by }\end{array}$ & U.S. unit & SI unit & $\begin{array}{l}\text { To convert SI to U.S., } \\
\text { multiply by }\end{array}$ \\
\hline 0.4047 & acre(s) & ha & 2.4711 \\
29,574 & $\mathrm{fl} \mathrm{oz}$ & $\mu \mathrm{L}$ & $3.3814 \times 10^{-5}$ \\
29.5735 & $\mathrm{fl} \mathrm{oz}$ & $\mathrm{mL}$ & 0.0338 \\
0.3048 & $\mathrm{ft}$ & $\mathrm{m}$ & 3.2808 \\
0.0929 & $\mathrm{ft}^{2}$ & $\mathrm{~m}^{2}$ & 10.7639 \\
3.7854 & $\mathrm{gal}$ & $\mathrm{L}$ & 0.2642 \\
2.54 & inch $(\mathrm{es})$ & $\mathrm{cm}$ & 0.3937 \\
25.4 & inch $(\mathrm{es})$ & $\mathrm{mm}$ & 0.0394 \\
1 & $\mathrm{micron}(\mathrm{s})$ & $\mu \mathrm{m}$ & 1 \\
1.6093 & $\mathrm{mile}(\mathrm{s})$ & $\mathrm{km}$ & 0.6214 \\
28.3495 & $\mathrm{Oz}$ & $\mathrm{g}$ & 0.0353 \\
1 & $\mathrm{ppm}$ & $\mathrm{mg} \cdot \mathrm{L}^{-1}$ & 1 \\
6894.7573 & $\mathrm{psi}$ & $\mathrm{Pa}$ & $1.4504 \times 10^{-4}$ \\
0.9072 & ton $(\mathrm{s})$ & $\mathrm{t}$ & 1.1023 \\
$\left({ }^{\circ} \mathrm{F}-32\right) \div 1.8$ & ${ }^{\circ} \mathrm{F}$ & ${ }^{\circ} \mathrm{C}$ & $\left({ }^{\circ} \mathrm{C} \times 1.8\right)+32$
\end{tabular}


and Clift, 2004; Greenslade and Ireson, 1986; Greenslade et al., 2014).

Ethyl formate is a naturally occurring compound that has been evaluated as a fumigant for stored grain, fruit, and vegetable applications and has been commercially adopted because of its valuable characteristics of rapid kill and consumer safety (Agarwal et al., 2015; Kim et al., 2013; Ren and Mahon, 2006; Ren et al., 2008). However, EF is highly absorbed in products such as strawberries (Fragaria $\times a n a n a s s a)$, apples (Malus $\times$ domestica), and several types of cut flowers because of their high moisture content and because $\mathrm{EF}$ is highly soluble in the water (Agarwal et al., 2015; Lee et al., 2013; Simpson et al., 2004). Some studies (Tarr et al., 2007) indicated that EF, as well as $\mathrm{EF}$ in combination with $10 \%$ carbon dioxide $\left(\mathrm{CO}_{2}\right)$, could be used for control of sawtoothed grain beetle (Oryzaephilus surinamensis) and confused flour beetle (Tribolium confusum) on dry vine fruit. Different levels of EF combined with low concentration of $\mathrm{PH}_{3} 0.5 \mathrm{mg} \cdot \mathrm{L}^{-1}$ for $2 \mathrm{~h}$ have resulted in high mortality of three species of aphids [cotton aphid (Aphis gossypii), green peach aphid (Myzus persicae), and turnip aphid (Lipaphis erysimi)], and there was significantly difference in the lethal concentration $\mathrm{LCT}_{50 \%}$ and $\mathrm{LCT}_{90 \%}$ values in comparison with $\mathrm{EF}$ and $\mathrm{PH}_{3}$ alone (Lee et al., 2014). Also, EF can cause high mortality in adults and nymphs of onion thrips (Thrips tabaci) on onion (Allium cepa) after $2 \mathrm{~h}$ exposure (Van Epenhuijsen et al., 2007).

Phosphine is a commercially available fumigant, which has been used for decades to control insects in stored grain. $\mathrm{PH}_{3}$ in combination with $\mathrm{CO}_{2}$, such as $\mathrm{ECO}_{2} \mathrm{FUME}^{* * *}$ $\left(2 \% \mathrm{PH}_{3}+98 \% \mathrm{CO}_{2}\right.$; Cytec Industries, Dongbu Hannong Co., Seoul, Korea), has been used for disinfestation of postharvest horticultural products (Jamieson et al., 2012; Williams et al., 2000). $\mathrm{PH}_{3}$ fumigation at low temperature has been shown to have high efficacy for postharvest control of western flower thrips (Frankliniella occidentalis) on lettuce (Lactuca sativa), broccoli (Brassica olevacea var. italica), asparagus (Asparagus officinalis), and strawberry (Liu, 2008). However, fumigation with $\mathrm{PH}_{3}$ has been known to cause a significant reduction in shelf and vase life of cut flowers with both 5.5 and $11 \mathrm{mg} \cdot \mathrm{L}^{-1}$ for $6 \mathrm{~h}$ exposure time to four types of cut flowers for controlling greenhouse thrips (Heliothrips haemorrhoidalis) and green peach aphids (Karunaratne et al., 1997).

There has been no published work on control of purple scum springtails on harvested celery. Under our current study, we researched the efficacy of $\mathrm{EF}, \mathrm{PH}_{3}$, and their combination for control of purple scum springtails on celery. In this preliminary study, optimal fumigant concentration, exposure period, and evaluation of phytotoxic damage to celery bunches are reported.

\section{Materials and methods Celery and target pest}

Celery infested with purple scum springtails was supplied by the Mandogalup Celery Farm (Sumich Group, Kwinana, Western Australia, Australia) located $23 \mathrm{~km}$ south of Perth, Western Australia (lat. $32.20^{\circ} \mathrm{S}$, long. $115.84^{\circ} \mathrm{E}$ ). Celery bunches were weighed with a digital balance, and their weight ranged between 686 and $1020 \mathrm{~g}$ per bunch.

The purple scum springtail species found in Western Australia were identified taxonomically by Majer et al. (2014) and current species have been confirmed by the Department of Primary Industries and Regional Development by mounting a number of specimens and following the Greenslade et al. (2014) classification key. Celery samples were stored in a cold room at $15{ }^{\circ} \mathrm{C}$ at Murdoch University (Murdoch, Australia) for 1-2 d.

\section{Reagents and apparatus}

Ethyl formate $97 \%$ purity was supplied by Sigma-Aldrich Co. (Castle Hill, Australia). A cylinderized $\mathrm{PH}_{3}$ gas mixed with nitrogen $\left(\mathrm{N}_{2}\right)$ [1.4\% $\mathrm{PH}_{3}$ with $98.6 \% \mathrm{~N}_{2}$ ] was supplied by BOC Australia (North Ryde, Australia). Ten-liter gas sampling bags (SKC Tedlar; Air-Met Scientific, Perth, Australia) were used to collect $\mathrm{PH}_{3}$ from the gas cylinder. One-liter gas sampling bags were used to take the liquid EF samples and made into vapor. One-liter erlenmeyer flasks (FE 1 L/3; Bibby Sterilin, Stone, UK) were used for the preparation of gas standards. An air vacuum pump (AP-02B; Tianjin Automatic Science Instrument Co., Tianjin, China) was used to suck air from the fumigation chambers to create negative pressure in preparation for fumigation.

A $100-\mu \mathrm{L}$ syringe $(005250$; SGE, Melbourne, Australia) was used for the injection of gas samples into the gas chromatograph (GC) and transfer liquid $\mathrm{EF}$ into fumigation chambers. A $5-\mu \mathrm{L}$ syringe $(5 \mathrm{R}-\mathrm{GT}$; SGE) was used to transfer liquid EF to prepare gas standards.

\section{Fumigation chamber}

A cylindrical stainless-steel chamber $(60 \times 36 \mathrm{~cm}$ i.d. $)$ with a capacity of $61 \mathrm{~L}$ was used. Each chamber was equipped with compression fittings (Swagelok Co., Perth, Australia) for attachment to a diaphragm pump between the top and bottom rim of the chamber. The removable metal lids were fitted with a centrally located septum for the introduction of gas during fumigation. The fumigation chamber had two gas sampling ports located on the side of the fumigation chamber. Each lid was fitted with gas-tight seals, which were pressure-tested before use.

For testing pressure halving time of the fumigation chambers, a digital manometer was connected to one of the compression fittings after securing the metal drum with lids. An air pump was used to apply an increased pressure of $250 \mathrm{~Pa}$ to the sealed drum via another compression fitting. Once the digital manometer displayed a value of $250 \mathrm{~Pa}$, the air pump was turned off and the ball valve tap closed. The air pressure was then timed until the value displayed was $125 \mathrm{~Pa}$, giving the drum's "pressure half-life." A half-life of more than 10 min indicated a well-sealed chamber suitable for fumigation.

\section{Determination of EF and $\mathrm{PH}_{3}$ concentration}

Ethyl formate was analyzed using a portable GC (Companion 600; DPS Instruments, Rancho Cucamonga, CA) installed with a flame ionization detector (FID). A $30 \mathrm{~m} \times$ $0.53-\mathrm{mm}$ (i.d.) $0.5-\mu \mathrm{m}$ capillary column (Zebron model ZB-WAX, Bl3844, part no. 7HK-G007-17; Phenomenex Co., Castle Hill, Australia) was used at an oven temperature of $95^{\circ} \mathrm{C} . \mathrm{N}_{2}$ carrier gas was used at a flow rate of $6 \mathrm{~mL} \cdot \mathrm{min}^{-1}$ at $103 \mathrm{~Pa}$. The concentrations of fumigants were monitored at different time intervals (depending on exposure time for each 
experiment) throughout the fumigation period.

Phosphine concentrations were determined at timed intervals using an GC (HP 5890, Series II; HewlettPackard Co., Wilmington, DE) equipped with a flame photometric detector (FPD) with a phosphorus filter following isothermal separation on a $30 \mathrm{~m} \times$ $0.25-\mathrm{mm}$ (i.d.), $0.25-\mu \mathrm{m}$, capillary column (Varian part no. CP8944; Sigma-Aldrich Co.) at oven temperature $50{ }^{\circ} \mathrm{C}$ and inlet temperature $105^{\circ} \mathrm{C}$. For FPD, the flow of hydrogen and air was 50 and $100 \mathrm{~mL} \cdot \mathrm{min}^{-1}$, respectively. Hydrogen was used as the carrier gas with a constant flow of $2 \mathrm{~mL} \cdot \mathrm{min}^{-1}$. After fumigation processes, two replicate injections were administered through each gas sampling port and injected into GC (two injections from the top and also two other injections from the bottom port of the fumigation chamber). Both EF and $\mathrm{PH}_{3}$ concentrations were calculated based on peak areas against external EF and $\mathrm{PH}_{3}$ gas standards.

\section{Fumigation of purple scum springtail infested celery with EF}

Three treatments consisting of 50,60 , and $90 \mathrm{mg} \cdot \mathrm{L}^{-1}$ of EF plus an untreated check were investigated for 1,2 , and $3 \mathrm{~h}$ the duration of exposure. Celery bunches were transferred after storage for $1-2 \mathrm{~d}$ from the $15^{\circ} \mathrm{C}$ cold room to the 23 to $25^{\circ} \mathrm{C}$ laboratory for up to $4 \mathrm{~h}$ before fumigation. Two replication fumigation chambers were used to treat the celery. Each chamber contained between 8545 and $9261 \mathrm{~g}$ for 10 bunches of celery held together with rubber bands and the bottom part of celery facing down (Fig. 1), with each chamber having $\approx 8 \%$ loading ratio of celery. Treatments of fumigation were carried out sequentially, starting with the first,

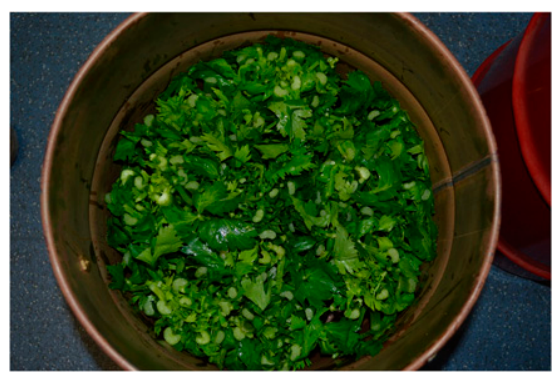

Fig. 1. Fumigation chamber [61 L (16.1 gal)] used for celery fumigations. second, and the third concentration of fumigants. The remaining celery bunches from the first experiment were stored at $15{ }^{\circ} \mathrm{C}$ cold room for next experiments. Ethyl formate experiments with two replication containers were repeated a second time for confirmation of phytotoxicity only by using fresh celery bunches that were stored for less than $24 \mathrm{~h}$ at $15{ }^{\circ} \mathrm{C}$ cold room. The untreated controls were prepared the same way in duplicate as EF treatments, except that no fumigant was applied. Before fumigation, the chambers were sealed tightly with locking rings attached to the lid.

Gas sampling bags were used to prepare fumigant at experimental concentrations. Calculated volumes of liquid EF were injected into $1-\mathrm{L}$ gas sampling bags and immersed in a hot water bath at $90^{\circ} \mathrm{C}$ for $10 \mathrm{~min}$ for complete vaporization of EF. Vaporized EF inflated the gas sampling bags. To facilitate injection of vaporized EF into experimental chambers, $\approx 3 \mathrm{~L}$ of air was sucked out using an air pump connected to the sealed chamber. The EF concentrations prepared in the gas sample bag were sucked into the chamber under negative pressure to balance the air pressure with ambient. Ethyl formate gas standard was prepared in a l-L erlenmeyer flask by taking out the estimated amount of air from the flask and injecting a calculated amount of liquid $\mathrm{EF}$ to the small piece of filter paper attached under the tight lid fitted with a rubber septum of the erlenmeyer flask. Headspace samples were taken from both gas sampling ports (top and bottom) of the fumigation chamber immediately and then 2 and $4 \mathrm{~h}$ later for each concentration $\left(50,60\right.$, and $\left.90 \mathrm{mg} \cdot \mathrm{L}^{-1}\right)$ along with gas standards and injected in duplicate into GC-FID. The fumigation was conducted at a laboratory temperature between 23 and $25^{\circ} \mathrm{C}$.

\section{Fumigation of infested celery with $\mathrm{PH}_{3}$}

Celery samples were brought from the $15{ }^{\circ} \mathrm{C}$ cold room and left for $\approx 4 \mathrm{~h}$ to bring to ambient laboratory temperature of 23 to $25{ }^{\circ} \mathrm{C}$ before fumigation. Ten celery bunches were placed in each chamber, with a loading ratio of $9.2 \%$. About $3 \mathrm{~L}$ of air were removed from each chamber before $\mathrm{PH}_{3}$ injection and balanced with ambient air pressure. The same procedure and the number of celery bunches were applied for untreated check treatments.

Four concentrations of $\mathrm{PH}_{3}$ were used: $1,1.5,2$, and $2.5 \mathrm{mg} \cdot \mathrm{L}^{-1}$ plus an untreated check treatment with three replications for each treatment. The GC reading was recorded immediately followed by $2,3,4,5$, and $6 \mathrm{~h}$ after treatment commenced. Gas standards were prepared in an erlenmeyer flask ( $1 \mathrm{~L})$ by removing the calculated amount of air and injecting a calculated amount of $\mathrm{PH}_{3}$ into the erlenmeyer flask. All headspace samples were collected from the top and bottom ports in each of the fumigation chamber and injected in duplicate into the GC along with $\mathrm{PH}_{3}$ standards.

\section{Fumigation of infested celery with the mixture of $\mathrm{EF}$ and $\mathrm{PH}_{3}$}

To test the effect of combined EF and $\mathrm{PH}_{3}$ on purple scum springtails, 10 bunches of celery were placed into two replication chambers similar to the previous (EF treatment) section. All experiments of the mixture of $\mathrm{EF}$ and $\mathrm{PH}_{3}$ were repeated twice by using fresh celery bunches that were stored for less than $24 \mathrm{~h}$ at $15^{\circ} \mathrm{C}$ cold room to confirm phytotoxicity only. The liquid EF was vaporized by using the gas sampling bag in hot water bath $\approx 90^{\circ} \mathrm{C}$ for $10 \mathrm{~min}$ until the bags were inflated by $\mathrm{EF}$ vaporization. Phosphine of required concentration was stored in separate gas sampling bags. Both EF and $\mathrm{PH}_{3}$ were injected into the chamber with $\mathrm{EF}$ as described previously. Three treatments of $\mathrm{EF}+\mathrm{PH}_{3}$ concentrations 20,30, and $40 \mathrm{mg} \cdot \mathrm{L}^{-1} \mathrm{EF}$, with $\mathrm{l} \mathrm{mg} \cdot \mathrm{L}^{-1}$ $\mathrm{PH}_{3}$, were used along with an untreated check treatment. All samples were taken from each (top and bottom) port of chamber immediately, 2 and $4 \mathrm{~h}$ later along with standards injected into the GC in duplicate.

\section{Mortality assessment of purple scum springtails}

The bioassay samples were retrieved at the end of the fumigation treatment by opening and aerating the fumigation chambers inside the fume hood for $\approx 30 \mathrm{~min}$. The fumigated celery samples were divided into two lots from each drum. Half of the sample lot from each drum was used for counting purple scum 
springtail mortality. The second half of the sample lot from each drum was stored at $15{ }^{\circ} \mathrm{C}$ and $65 \%$ to $70 \%$ relative humidity for product quality and phytotoxicity studies.

After aeration, the mortality of purple scum springtails was evaluated by transferring five celery bunches from each replication to a white plastic tray for mortality assessment. This was carried out by dismantling all leaves of celery from external to internal leaves and carefully transferring all dead and live insects into a $9-\mathrm{cm}$ glass petri dish to ensure that all purple scum springtails were recovered. A magnifying glass was used to determine dead and live purple scum springtails. Similarly, mortality assessment was conducted for untreated check treatments.

\section{Evaluation of fumigant phytotoxicity}

Phytotoxicity for $\mathrm{EF}, \mathrm{PH}_{3}$, and their combination treatments was evaluated by cutting the treated and untreated celery bunches in half and looking for any damage or color change relative to untreated control samples. The observation of fumigant damages was taken every day from day 2 until day 7 .

\section{Sensory and taste evaluation}

Sensory and taste evaluation were carried out by selected $20 \mathrm{vol}-$ unteers (10 males and 10 females, between the ages of 30 and 60 years) to check and taste the treated and untreated celeries. Before conduct sensory and taste tests, $\mathrm{PH} 3$ fumigated celery was aired for $2 \mathrm{~h}$ in under fume hood. The fumigated and untreated control celery samples were washed, leaves removed, and cut into pieces $(15 \mathrm{~cm}$ long) for sensory and taste test. Treated and untreated celery were placed in two blank coded plates and the panel was asked to randomly pick the celery and rate their visual attributes related to color and taste related to flavor (characteristic flavor and odor), texture (crispness and juiciness), and smells from a scale of 1 to $9(1=$ dislike extremely to $9=$ like extremely) (Barrett et al., 2010; Raffo et al., 2006; Yommi et al., 2013).

Statistical analysis. Mortality for all treatments was calculated with one-way analysis of variance (ANOVA) using SPSS Advanced Statistics software (version 24.0; IBM Corp, Armonk, NY) at the least significant difference level (5\%) and Tukey's $95 \%$ confidence intervals. The variation of all treatments and standards were assessed with duplicate injections and gas chromatography data. The average and SD of EF, $\mathrm{PH}_{3}$, and their combination absorption by celery were calculated on the basis of peak areas against the external gas standards of EF and $\mathrm{PH}_{3}$ using Microsoft Excel 2010 (Microsoft Co., Perth, Australia). The sensory evaluation results were treated by ANOVA at a significant level of $5 \%$.

\section{Results}

SORPTION OF FUMIGANTS BY CELERY. The concentration of EF and $\mathrm{PH}_{3}$ in the fumigation chambers was measured during $4 \mathrm{~h}$ of fumigation with $\mathrm{EF}$ and $\mathrm{EF}+\mathrm{PH}_{3}$, and $6 \mathrm{~h}$ for $\mathrm{PH}_{3}$. The concentrations of fumigants are shown in Figs. 2-4. All concentrations of EF decreased rapidly within $0.5 \mathrm{~h}$ (Fig. 2) as EF was absorbed by the commodity. The concentration of EF in the $90 \mathrm{mg} \cdot \mathrm{L}^{-1}$ treatment recorded a decline of $70 \%$ from the initial dose and more than $80 \%$ for the initial EF concentrations of 50 and $60 \mathrm{mg} \cdot \mathrm{L}^{-1}$. After $2 \mathrm{~h}$ of fumigation, $85 \%$ to $90 \%$ of $\mathrm{EF}$ was absorbed by the commodity for all applied concentrations of EF. For the $\mathrm{PH}_{3}$ fumigation after 2 and $6 \mathrm{~h}$, $\approx 40 \%$ to $50 \%$ and $60 \%$ to $70 \%$ of $\mathrm{PH}_{3}$ was absorbed by the commodity for applied concentrations of $1,1.5$, and 2 $\mathrm{mg} \cdot \mathrm{L}^{-1}$, respectively. However, for 2.5 $\mathrm{mg} \cdot \mathrm{L}^{-1} \mathrm{PH}_{3}, \approx 22 \%$ and $32 \%$ of the initial applied concentration was lost over 2 and 6 h, respectively (Fig. 3).

For the $\mathrm{EF}+\mathrm{PH}_{3}$ combination fumigation treatments, less than half of $\mathrm{EF}$ and $\approx 50 \% \mathrm{PH}_{3}$ was lost within $2 \mathrm{~h}$ (Fig. 4). Generally, after $4 \mathrm{~h}$ of fumigation, $\approx 90 \%$ of $\mathrm{EF}$ and $\approx 40 \%$ of $\mathrm{PH}_{3}$ were lost from the headspace of fumigation chambers (Figs. 1-4).

BioAssay of EF ALONE ON PURPLE SCUM SPRINGTAILS. The total number of purple scum springtails tested varied in all treatments because of natural infestation. The numbers of pests ranged between 132 and 238 purple scum springtails per treatment. With celery fumigated in chambers with $\mathrm{EF}$ at the concentration of 50 $\mathrm{mg} \cdot \mathrm{L}^{-1}$, the mortality of purple scum springtails was $82.77 \%, 91.58 \%$, and $93.28 \%$ for 1,2 , and $4 \mathrm{~h}$ exposure, respectively (Table 1 ). The second treatment of EF at a concentration of $60 \mathrm{mg} \cdot \mathrm{L}^{-1}$ for $\mathrm{l}, 2$, and $4 \mathrm{~h}$ exposure showed observed mortality of $98.21 \%, 97.46 \%$, and $96.04 \%$, respectively. In the third treatment of $\mathrm{EF}$, with a concentration of 90 $\mathrm{mg} \cdot \mathrm{L}^{-1}$, the observed mortality was $98.73 \%$ and $100 \%$ for $\mathrm{l}$ and $2 \mathrm{~h}$ exposure, respectively. These bioassay results show that there is a significant difference in the level of mortality between 1,2 , and $4 \mathrm{~h}$ exposure with $\mathrm{EF}$ alone compared with the untreated check. Also, there is a significant difference in the level of mortality among the concentrations 50,60 , and $90 \mathrm{mg} \cdot \mathrm{L}^{-1}$ for all fumigation times. There was no significant difference in mortality between the concentrations of 60 and $90 \mathrm{mg} \cdot \mathrm{L}^{-1}$ for any duration of fumigation. The high mortality of $100 \%$ was achieved only at $90 \mathrm{mg} \cdot \mathrm{L}^{-1}$ after $2 \mathrm{~h}$ exposure.

The results of this study indicate that increasing EF concentration plays a more significant role than the duration of fumigation on mortality of purple scum springtails. There was a significant effect of concentration and time on purple scum springtail mortality $(\mathrm{F}=5.773, P<0.007)$. The relationship between concentration and time was assessed by variance analysis and accounted for $R^{2}=$ 0.999 and adjusted $R^{2}=0.998$.

BioAssay OF $\mathrm{PH}_{3}$ ALONE ON PURPLE SCUM SPRINGTAILS. In the $\mathrm{PH}_{3}$-only treatment, varying numbers of purple scum springtails (80217) were tested per treatment on purple scum springtail-infested celery. The relatively low and variable number of purple scum springtails per treatment is due to the celery being naturally infested.

Initially, two treatment of $\mathrm{PH}_{3}$ concentrations ( 1 and $1.5 \mathrm{mg} \cdot \mathrm{L}^{-1}$ ) were tested (Table 2 ). The mortality achieved was $24.33 \%, 24.26 \%$, and $26.40 \%$ at $1 \mathrm{mg} \cdot \mathrm{L}^{-1}$ for 2,4 , and $6 \mathrm{~h}$ exposure time, respectively, and $37.20 \%, 20.90 \%$, and $35.80 \%$ at 1.5 $\mathrm{mg} \cdot \mathrm{L}^{-1}$ for 2,4 , and $6 \mathrm{~h}$ exposure time, respectively. Other treatments of $\mathrm{PH}_{3}$ concentrations used two concentrations that were 2 and $2.5 \mathrm{mg} \cdot \mathrm{L}^{-1}$ for 2,4 , and $6 \mathrm{~h}$ exposure. The results show mortality of $64.70 \%, 70.73 \%$, and $73.23 \%$ at $2 \mathrm{mg} \cdot \mathrm{L}^{-1}$ of $\mathrm{PH}_{3}$ and $53.86 \%, 73.63 \%$, and $100 \%$ achieved at $2.5 \mathrm{mg} \cdot \mathrm{L}^{-1}$ for 2,4 , and $6 \mathrm{~h}$ exposure, respectively. Mortality varied significantly by concentration and time of 


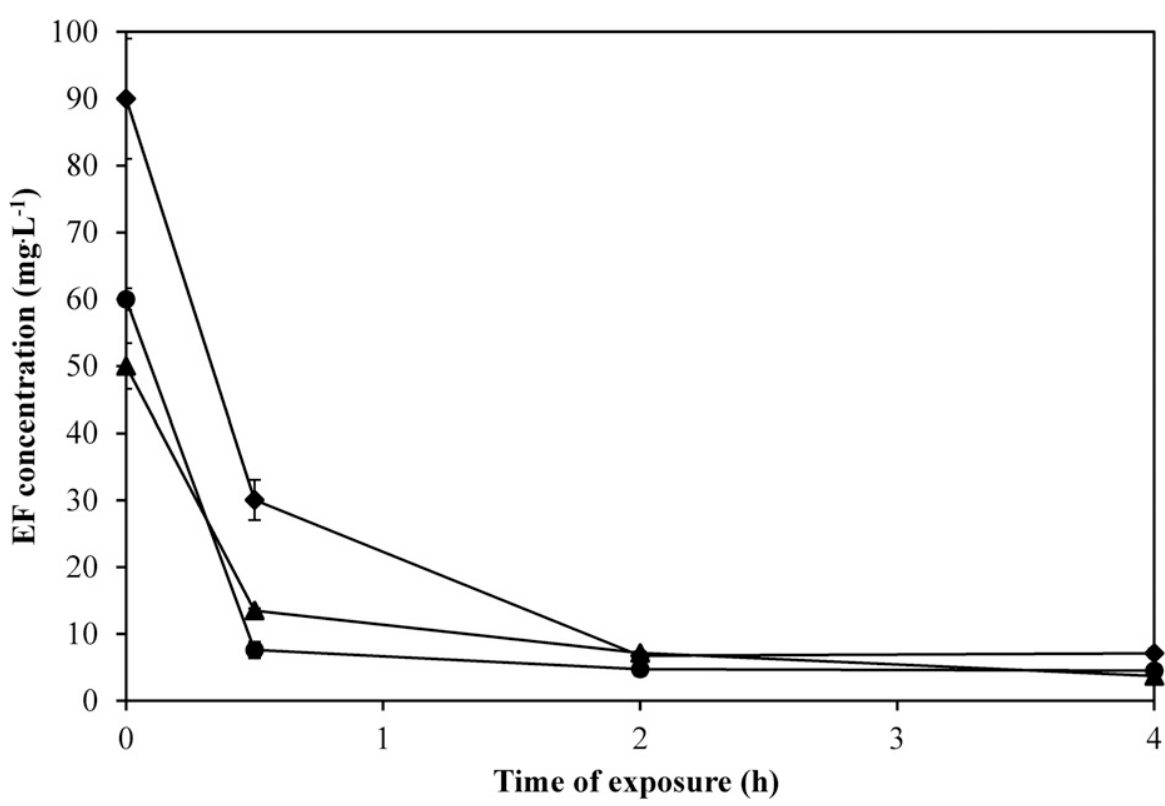

Fig. 2. The concentration of ethyl formate (EF) with time of exposure in the headspace of fumigation chambers containing celery bunches at $50(-\Delta-), 60(-\bullet)$, and $90(--) \mathrm{mg} \cdot \mathrm{L}^{-1}$ for 1,2 , and $4 \mathrm{~h}$ exposure, respectively. Vertical bars represent $\mathrm{SD} ; 1 \mathrm{mg} \cdot \mathrm{L}^{-1}=335 \mathrm{ppm}(\mathrm{v} / \mathrm{v})$.

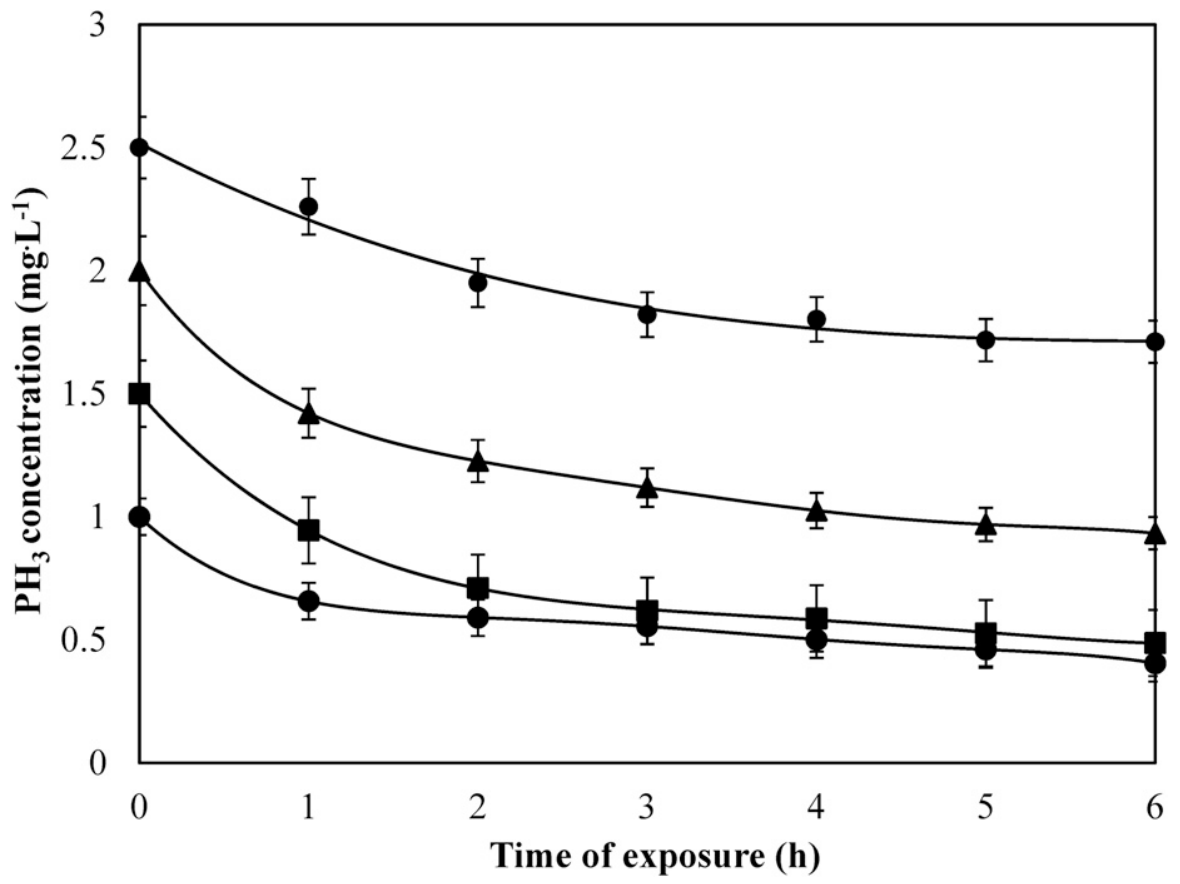

Fig. 3. The concentration of phosphine $\left(\mathrm{PH}_{3}\right)$ with time of exposure in the headspace of fumigation chambers containing celery bunches at $1(-\bullet-), 1.5(-\square-)$, $2(-\Delta-)$, and $2.5(-\bullet) \mathrm{mg} \cdot \mathrm{L}^{-1}$ for 2,4 , and $6 \mathrm{~h}$ exposure, respectively. Vertical bars represent SD; $1 \mathrm{mg} \cdot \mathrm{L}^{-1}=730 \mathrm{ppm}(\mathrm{v} / \mathrm{v})$.

exposure $(\mathrm{F}=4.663, P<0.001)$. The relationship between concentration and time variance accounted for $R^{2}=$ 0.940 and adjusted $R^{2}=0.912$.

BioAssay OF $\mathrm{PH}_{3}$ PLUS EF IN COMBINATION ON PURPLE SCUM SPRINGTAILS. To reduce phytotoxicity on EF-treated celery, the dose of EF was decreased to 20,30 , and 40 $\mathrm{mg} \cdot \mathrm{L}^{-1}$ and combined with $1 \mathrm{mg} \cdot \mathrm{L}^{-1}$ $\mathrm{PH}_{3}$. The combination of $\mathrm{PH}_{3}$ and EF was tested on purple scum springtail-infested celery with three concentrations of EF tested: 20, 30, and 40 $\mathrm{mg} \cdot \mathrm{L}^{-1}$ each combined with $1 \mathrm{mg} \cdot \mathrm{L}^{-1}$ of $\mathrm{PH}_{3}$. The number of target pests ranged between 101 and 211 insects per treatment.

The mortality of purple scum springtails was $100 \%$ for 2 and $4 \mathrm{~h}$ exposure at $40 \mathrm{mg} \cdot \mathrm{L}^{-1}$ of $\mathrm{EF}$ mixed with $1 \mathrm{mg} \cdot \mathrm{L}^{-1} \mathrm{PH}_{3}$ compared with the untreated check treatment. Mortality of $98.8 \%$ and $100 \%$ mortality was achieved at $30 \mathrm{mg} \cdot \mathrm{L}^{-1}$ of $\mathrm{EF}$ mixed with $1 \mathrm{mg} \cdot \mathrm{L}^{-1} \mathrm{PH}_{3}$ for 2 and $4 \mathrm{~h}$ exposure, respectively (Table 3 ). Mortality at $20 \mathrm{mg} \cdot \mathrm{L}^{-1}$ of $\mathrm{EF}$ with 1 $\mathrm{mg} \cdot \mathrm{L}^{-1}$ of $\mathrm{PH}_{3}$ was $89.5 \%$ and $95.5 \%$ for 2 and $4 \mathrm{~h}$ exposure, respectively. The interaction between concentration and time on purple scum springtail mortality was significant $(\mathrm{F}=$ 16.56, $P<0.001$ ). The relationship between concentration and time was assessed by variance analysis and accounted for $R^{2}=1.000$ and adjusted $R^{2}=1.000$.

EFFECT OF FUMIGANTS ON CELERY QUALITY AND PHYTOTOXICITY. It was observed that EF fumigation can result in significant phytotoxicity of celery. Symptoms are changes in the color of leaves especially inside layers of young leaves, which turn brown. Our results indicate that all concentrations of EF used in this study affected celery and caused phytotoxicity. Damage was apparent in two ways: first, only young leaves were damaged at low EF concentrations, and second, both old and young leaves of celery were damaged at high concentrations of EF. Importantly, celery subjected to $\mathrm{PH}_{3}$ treatments alone at various doses showed no evident phytotoxicity.

Damage to celery appeared within $\mathrm{l} d$ of treatment with 20 $\mathrm{mg} \cdot \mathrm{L}^{-1} \mathrm{EF}$ plus $\mathrm{l} \mathrm{mg} \cdot \mathrm{L}^{-1} \mathrm{PH}_{3}$. The browning of leaves appeared almost immediately at 30 and $40 \mathrm{mg} \cdot \mathrm{L}^{-1}$ doses of EF. The quality of celery was reduced by wilting of outer foliage and yellowing of inside layered leaves by $\mathrm{EF}$ and the mixture of $\mathrm{EF}+\mathrm{PH}_{3}$ after $2-5 \mathrm{~d}$ of treatment depending on the concentration of fumigant.

The scores of sensory test for both treated and untreated celery ranged between seven and nine for all attributes (Table 4), corresponding to "like moderately" to "like extremely." There were no statistically significantly difference $(P>$ 


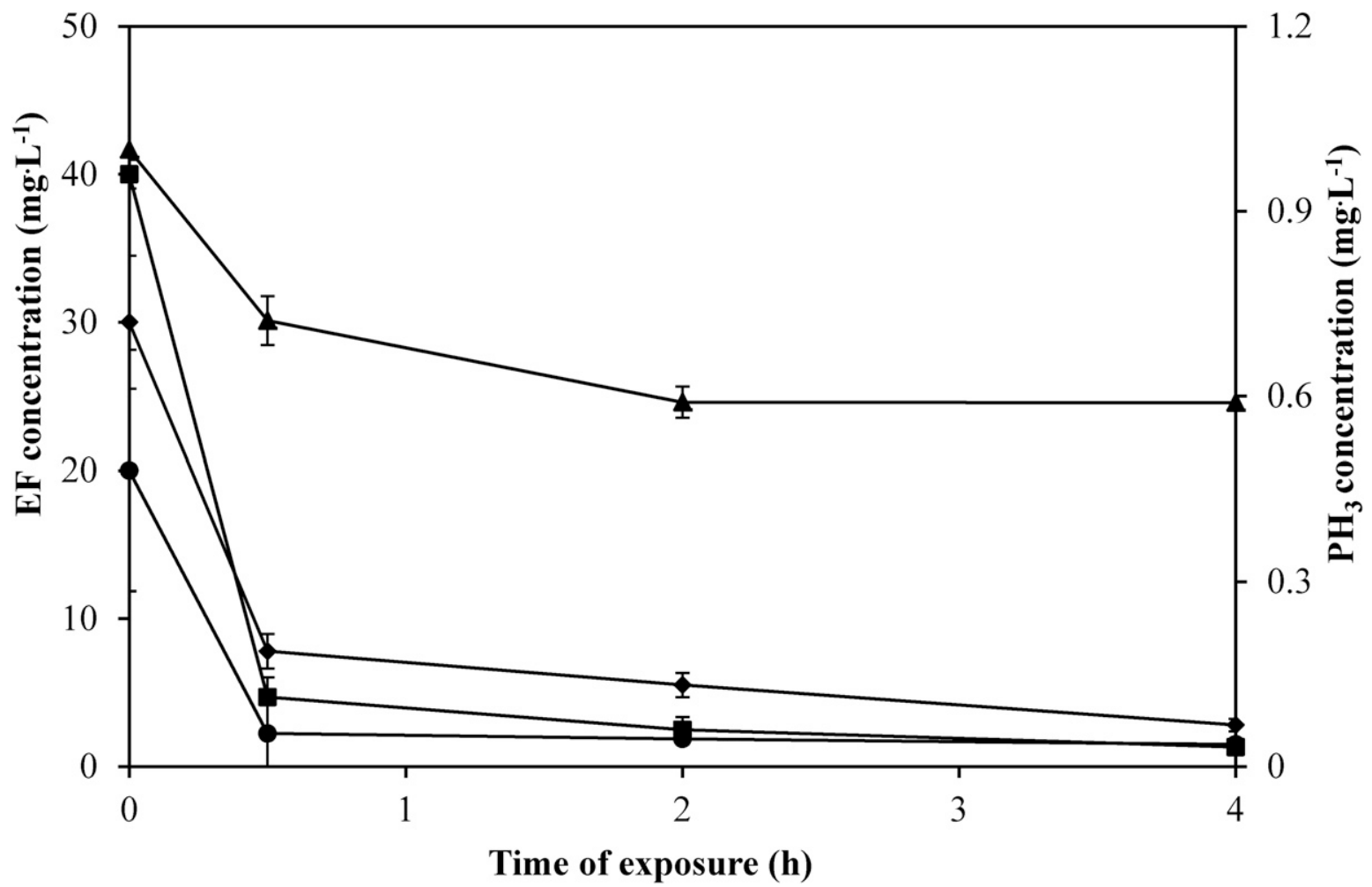

Fig. 4. The concentrations of ethyl formate (EF) and phosphine $\left(\mathrm{PH}_{3}\right)$ with time of exposure in the headspace of fumigation chambers containing celery bunches during fumigation with the combination of EF at $20(-\bullet-), 30(-\downarrow-)$, and $40(-\square-)$ mg. $\mathrm{L}^{-1}$ plus $\mathrm{PH}_{3}\left[-\Delta-\left(1 \mathrm{mg} \cdot \mathrm{L}^{-1}\right)\right]$, respectively, for 2 and $4 \mathrm{~h}$ exposure. Vertical bars represent SD; $1 \mathrm{mg} \cdot \mathrm{L}^{-1}=335 \mathrm{ppm}(\mathrm{v} / \mathrm{v})$ for EF and $1 \mathrm{mg} \cdot \mathrm{L}^{-1}=730 \mathrm{ppm}(\mathrm{v} / \mathrm{v})$ for $\mathrm{PH}_{3}$.

Table 1. The mortality of purple scum springtails after 1, 2, and $4 \mathrm{~h}$ exposure to ethyl formate (EF) at different concentrations in fumigation chambers containing celery.

\begin{tabular}{|c|c|c|c|c|}
\hline EF concn. $\left(\mathrm{mg} \cdot \mathrm{L}^{-1}\right)^{\mathrm{z}}$ & Time of exposure (h) & $N^{y}$ & Mortality $[$ mean \pm SE $(\%)]$ & $95 \%$ CI (range) ${ }^{x}$ \\
\hline \multirow[t]{3}{*}{0 Untreated check } & 1 & 147 & $0 \pm 0 \mathrm{a}^{\mathrm{w}}$ & 0 \\
\hline & 2 & 168 & $0 \pm 0 \mathrm{a}$ & 0 \\
\hline & 4 & 135 & $0 \pm 0 \mathrm{a}$ & 0 \\
\hline \multirow[t]{3}{*}{50} & 1 & 132 & $82.77 \pm 1.17 b$ & $79.95-85.59$ \\
\hline & 2 & 166 & $91.58 \pm 0.90 \mathrm{c}$ & $89.42-93.74$ \\
\hline & 4 & 164 & $93.28 \pm 0.10 \mathrm{~cd}$ & $93.03-93.53$ \\
\hline & 4 & 156 & $96.04 \pm 1.87 \mathrm{cde}$ & $91.55-100.53$ \\
\hline \multirow[t]{2}{*}{90} & 1 & 140 & $98.73 \pm 1.03 \mathrm{de}$ & $96.25-101.22$ \\
\hline & 2 & 193 & $100.0 \pm 0 \mathrm{e}$ & $100-100$ \\
\hline $\mathrm{LSD}_{0.05^{\mathrm{v}}}$ & & & 3.512 & \\
\hline
\end{tabular}

${ }^{\mathrm{z}} 1 \mathrm{mg} \cdot \mathrm{L}^{-1}=335 \mathrm{ppm}$.

${ }^{\mathrm{y}}$ Total number of purple scum springtails.

${ }^{\mathrm{x}} 95 \%$ confidence interval $(\mathrm{CI})$.

${ }^{\text {w}}$ Mean mortality followed by the same letters in each group were not significantly different based on Tukey's differences multiple range test, $P>0.05$.

'Least significant difference at $P=0.05$.

0.05 ) between untreated control and treated samples.

\section{Discussion}

Purple scum springtails are a common insect in Australia, occasionally found on fresh celery. This has led to export rejection to Middle East countries where it is a quarantine pest requiring fumigation. Our investigations showed that $\mathrm{EF}, \mathrm{PH}_{3}$, and their combination had a significant effect on purple scum springtail mortality. Experimental concentrations of fumigants $\mathrm{EF}, \mathrm{PH}_{3}$, and their combination were found to decrease significantly over time, which may be attributed to the absorption by celery bunches because of the high surface area and very high moisture content of the commodity (Figs. 1-4). The sorption of fumigants $\mathrm{EF}$ and $\mathrm{PH}_{3}$ is known to depend on several conditions such as the type of commodity, target pest, temperature, moisture content, particle size and composition, exposure time, and fumigant 
Table 2. The mortality of purple scum springtails after 2,4 , and $6 \mathrm{~h}$ exposure to phosphine $\left(\mathrm{PH}_{3}\right)$ at different concentrations in fumigation chambers containing celery.

\begin{tabular}{|c|c|c|c|c|}
\hline $\mathrm{PH}_{3}$ concn. $\left(\mathrm{mg} \cdot \mathrm{L}^{-1}\right)^{\mathrm{z}}$ & Time of exposure (h) & $N^{y}$ & Mortality $[$ mean \pm SE $(\%)]$ & $95 \%$ CI (range) $)^{x}$ \\
\hline \multirow[t]{3}{*}{0 Untreated check } & 2 & 133 & $7.50 \pm 1.46 \mathrm{a}^{\mathrm{w}}$ & $3.23-18.25$ \\
\hline & 4 & 217 & $3.09 \pm 2.64 \mathrm{a}$ & $0.62-6.82$ \\
\hline & 6 & 156 & $2.05 \pm 3.06 \mathrm{a}$ & $1.96-6.07$ \\
\hline \multirow[t]{3}{*}{1} & 2 & 127 & $24.32 \pm 3.62 \mathrm{ab}$ & $6.94-41.71$ \\
\hline & 4 & 101 & $24.25 \pm 1.00 \mathrm{ab}$ & $14.05-34.45$ \\
\hline & 6 & 151 & $26.38 \pm 0.58 \mathrm{abc}$ & $19.37-33.39$ \\
\hline 1.5 & 6 & 130 & $35.79 \pm 3.70 \mathrm{bc}$ & $28.50-43.08$ \\
\hline \multirow[t]{3}{*}{2} & 2 & 80 & $64.69 \pm 3.74 \mathrm{de}$ & $49.06-80.32$ \\
\hline & 4 & 134 & $70.72 \pm 0.16 \mathrm{ef}$ & $61.79-79.64$ \\
\hline & 6 & 121 & $73.20 \pm 2.72 \mathrm{ef}$ & $64.28-82.13$ \\
\hline \multirow[t]{2}{*}{2.5} & 2 & 155 & $53.88 \pm 3.02 \mathrm{cde}$ & $38.78-68.99$ \\
\hline & 4 & 97 & $73.59 \pm 3.74 \mathrm{ef}$ & $62.58-84.59$ \\
\hline
\end{tabular}

${ }^{\mathrm{z}} 1 \mathrm{mg} \cdot \mathrm{L}^{-1}=730 \mathrm{ppm}$.

${ }^{y}$ Total number of purple scum springtails.

${ }^{\mathrm{x}} 95 \%$ confidence interval $(\mathrm{CI})$.

"Mean mortality followed by the same letters in each group was not significantly different based on Tukey's differences multiple range test, $P>0.05$.

"Least significant difference at $P=0.05$.

Table 3. The mortality of purple scum springtails exposed to various concentrations of the combination of ethyl formate (EF) plus phosphine $\left(\mathrm{PH}_{3}\right)$ for 2 and $4 \mathrm{~h}$ in fumigation chambers containing celery.

\begin{tabular}{|c|c|c|c|c|}
\hline $\mathrm{EF}+\mathrm{PH}_{3}$ concn. $\left(\mathrm{mg} \cdot \mathrm{L}^{-1}\right)^{\mathrm{z}}$ & Time of exposure $(h)$ & $N^{\mathrm{y}}$ & Mortality $[$ mean \pm SE $(\%)]$ & $95 \%$ CI (range) \\
\hline \multirow[t]{2}{*}{$0+0$ Untreated check } & 2 & 168 & $0 \pm 0 a^{w}$ & 0 \\
\hline & 4 & 135 & $0 \pm 0 \mathrm{a}$ & 0 \\
\hline $20+1$ & 2 & 211 & $89.50 \pm 0.57 b$ & $85.41-99.10$ \\
\hline & 4 & 158 & $95.50 \pm 0.17 \mathrm{c}$ & $87.69-97.78$ \\
\hline \multirow[t]{2}{*}{$30+1$} & 2 & 184 & $98.80 \pm 0.99 \mathrm{~d}$ & $96.39-101.17$ \\
\hline & 4 & 192 & $100.00 \pm 0.00 \mathrm{~d}$ & $100-100$ \\
\hline
\end{tabular}

${ }^{\mathrm{z}} \mathrm{l} \mathrm{mg} \cdot \mathrm{L}^{-1}=335 \mathrm{ppm}(\mathrm{v} / \mathrm{v})$ for $\mathrm{EF}$ and $\mathrm{l} \mathrm{mg} \cdot \mathrm{L}^{-1}=730 \mathrm{ppm}(\mathrm{v} / \mathrm{v})$ for $\mathrm{PH}_{3}$.

${ }^{\mathrm{y}}$ Total number of purple scum springtails.

${ }^{\mathrm{x}} 95 \%$ confidence interval $(\mathrm{CI})$.

${ }^{w}$ Mean mortality followed by the same letters in each group were not significantly different based on Tukey's differences multiple range test, $P>0.05$.

'Least significant difference at $P=0.05$.

dose (Berck, 1968; Dhaliwal, 1975). Furthermore, Reddy et al. (2007) reported that $\mathrm{PH}_{3}$ concentration might vary according to food commodity types and found that the $\mathrm{PH}_{3}$ concentration in the headspace of the commodities varied from 0 to $>2000$ $\mathrm{ppm}$. The higher moisture content of fresh products may be one of the contributing factors for sorption of $\mathrm{PH}_{3}$, as outlined in their studies where $\mathrm{PH}_{3}$ was applied to 74 products with high moisture content. This result is consistent with previous experiments that demonstrated that EF and $\mathrm{PH}_{3}$ can be significantly absorbed by the commodity or broken down to by-products because of the high moisture content of the commodity (Agarwal et al., 2015; Reddy et al.,
2007). Furthermore, the toxicity to the pest can be increased with longer exposure time (Lee et al., 2015; Liu, 2011; Ren et al., 2011; Van Epenhuijsen et al., 2007).

In the current study, mortality of purple scum springtails varied among different $\mathrm{EF}$ concentrations, with $100 \%$ mortality achieved at $90 \mathrm{mg} \cdot \mathrm{L}^{-1}$ within $2 \mathrm{~h}$. The results for $\mathrm{EF}$ indicate a significant increase in purple scum springtail mortality with increasing exposure to EF. This result is consistent with findings of other experiments which showed that vacuum fumigation of packaged lettuce with $0.5 \%, 1.0 \%$, and $1.5 \%$ of EF for $2 \mathrm{~h}$ had little impact on the quality of lettuce while achieving high mortality of green peach aphid. Ethyl formate is approved for treatment of an export paprika (Capsicum annuum) market, as well as tomatoes (Solanum lycopersicum) in Korea (Kim et al., 2013). In addition, EF achieved high mortality against cotton aphids and two-spotted mites (Tetranychus urticae) (Kim et al., 2013; Lee et al., 2013; Stewart and Aharoni, 1983).

Table 1 shows the different percentage mortality of purple scum springtails with EF fumigation alone.

A high dose of EF of $90 \mathrm{mg} \cdot \mathrm{L}^{-1}$ achieved $100 \%$ mortality, compared with relatively low mortality at a concentration of $50 \mathrm{mg} \cdot \mathrm{L}^{-1}$ of only $91.58 \%$ over the same exposure period. These results of high mortality on purple scum springtails may be attributable to fumigant penetration 
Table 4. Effect of fumigation on quality and sensory scores ( 1 to 9 hedonic scale) of celery.

\begin{tabular}{|c|c|c|c|c|c|}
\hline Quality attribute & Treatment & $N^{z}$ & Score $[\text { mean } \pm \text { SE }(1 \text { to } 9)]^{\mathrm{y}}$ & $95 \%$ CI (range) ${ }^{x}$ & $P$ value \\
\hline & Control & 20 & $8.00 \pm 0.07$ & $7.85-8.15$ & 0.574 \\
\hline & Control & 20 & $7.75 \pm 0.14$ & $7.45-8.05$ & 0.313 \\
\hline \multirow[t]{2}{*}{ Flavor and taste } & $\mathrm{PH}_{3}$ treated & 20 & $7.85 \pm 0.19$ & $7.44-8.26$ & \multirow[t]{2}{*}{0.702} \\
\hline & Control & 20 & $7.95 \pm 0.17$ & $7.59-8.31$ & \\
\hline \multirow[t]{2}{*}{ Aroma and smell } & $\mathrm{PH}_{3}$ treated & 20 & $7.45 \pm 0.56$ & $6.91-7.99$ & \multirow[t]{2}{*}{0.387} \\
\hline & Control & 20 & $7.75 \pm 0.22$ & $7.27-8.23$ & \\
\hline
\end{tabular}

${ }^{\mathrm{z}}$ Number of panelists who determined the sensory scores.

${ }^{\mathrm{y}} \mathrm{l}=$ dislike extremely and $9=$ like extremely.

${ }^{\mathrm{x}} 95 \%$ confidence interval (CI) for mean.

$\mathrm{PH}_{3}=$ phosphine .

into each celery bunch. This result is consistent with results of the past studies that showed $100 \%$ mortality against indian meal moth (Plodia interpunctella) and confused flour beetle by using EF alone on dried vine fruit and also high EF concentration caused high mortality on the eucalyptus weevil (Gonipterus platensis) in export apples (Agarwal et al., 2015; Tarr et al., 2007).

Fumigation of celery bunches with $\mathrm{PH}_{3}$ alone was studied, and $100 \%$ mortality was achieved at 2.5 $\mathrm{mg} \cdot \mathrm{L}^{-1}$ after $6 \mathrm{~h}$ fumigation. Lower doses of $1,1.5$, and $2 \mathrm{mg} \cdot \mathrm{L}^{-1}$ also caused mortality on purple scum springtails, but levels of mortality were less (Table 2). These results are consistent with Liu (2009) who reported that $\mathrm{PH}_{3}$ fumigant caused $100 \%$ mortality at $1.4 \mathrm{mg} \cdot \mathrm{L}^{-1}$ after $24 \mathrm{~h}$ fumigation for western flower thrips on different vegetables such as lettuce, broccoli, and asparagus, which were successfully fumigated at low temperature $\left(2^{\circ} \mathrm{C}\right)$ without injury to these vegetables. For controlling lettuce aphids using $\mathrm{PH}_{3}$ fumigation, 2.4 $\mathrm{mg} \cdot \mathrm{L}^{-1}$ of $\mathrm{PH}_{3}$ achieved $100 \%$ mortality over $72 \mathrm{~h}$ fumigation at low temperature $\left(2^{\circ} \mathrm{C}\right)$ ( $\left.\mathrm{Liu}, 2009\right)$. Moon (2012) reported that concentrations of $\mathrm{PH}_{3}$ should be more than $2 \mathrm{~g} \cdot \mathrm{m}^{-3}$ for $>24 \mathrm{~h}$ exposure for control of cotton aphid at $8{ }^{\circ} \mathrm{C}$ on cut flowers and nursery stock.

Current studies show high mortality over short fumigation periods with the toxicity of EF plus $\mathrm{PH}_{3}$ being much higher compared with $\mathrm{PH}_{3}$ or EF alone. Low concentration of $\mathrm{EF}$ ( 30 and $40 \mathrm{mg} \cdot \mathrm{L}^{-1}$ ) mixed with $\mathrm{PH}_{3}\left(1 \mathrm{mg} \cdot \mathrm{L}^{-1}\right)$ at 2 and $4 \mathrm{~h}$ exposure gave $100 \%$ mortality compared with the high dose of $\mathrm{EF}$ or $\mathrm{PH}$ at the same exposure time when used alone $(100 \%$ mortality achieved at $90 \mathrm{mg} \cdot \mathrm{L}^{-1} \mathrm{EF}$ alone for $2 \mathrm{~h}$ exposure and also with $\mathrm{PH}_{3}$ at $2.5 \mathrm{mg} \cdot \mathrm{L}^{-1}$ alone at $6 \mathrm{~h}$ ).

Hence, we believe that there is a synergistic effect between EF and $\mathrm{PH}_{3}$ for control of purple scum springtails and the combination produces a greater effect than either EF or $\mathrm{PH}_{3}$ alone. At concentrations of 30 and $40 \mathrm{mg} \cdot \mathrm{L}^{-1}$ of EF combined with 1 $\mathrm{mg} \cdot \mathrm{L}^{-1} \mathrm{PH}_{3}, 100 \%$ mortality was achieved compared with $20 \mathrm{mg} \cdot \mathrm{L}^{-1}$ of $\mathrm{EF}$ combined with the same amount of $\mathrm{PH}_{3}$, which gave less mortality over the same exposure time. This result shown in Table 3 is consistent with Lee et al. (2015) who demonstrated a synergistic effect between $\mathrm{EF}$ and $\mathrm{PH}_{3}$ for control of cotton aphids when applied in combination. They showed that the fumigant combination can cause high toxicity against all stages of citrus mealybug (Planococcus citri) and less damage to the commodities at low temperature $\left(8{ }^{\circ} \mathrm{C}\right.$ ) for $4 \mathrm{~h}$ (Yang et al., 2016). There have been a number of research studies looking to reduce the fumigation period and increase $\mathrm{PH}_{3}$ effectiveness with mixtures of different gases. For example, Liu $(2008,2011)$ found that exposure time of $\mathrm{PH}_{3}$ can be reduced at low temperature and still control several postharvest pests, such as western flower thrips and grape mealybug (Pseudococcus maritimus), by using oxygenated $\mathrm{PH}_{3}$.

All fumigants were effective against purple scum springtails in given short treatment times for exporting fresh produce with respect to disinfesting produce of live insects. However, EF fumigant alone and in combination with $\mathrm{PH}_{3}$ affected the quality of celery and caused phytotoxicity symptoms. The observation of celery phytotoxicity from $\mathrm{EF}$ and the combination of $\mathrm{EF}$ and $\mathrm{PH}_{3}$ demonstrated that high sorption of $\mathrm{EF}$ by the commodity is phytotoxic, even at low concentrations of EF or short fumigation times. Phytotoxicity of the fumigant to the commodities is very much dependent on the type of commodity treated, and the interaction of fumigant or its by-product with the chemical constituents of the commodities. These results are supported by Weller and Graver (1998) and Zhang and Van Epenhuijsen (2004) who reported that EF causes high phytotoxicity on cut flowers. In some previous studies, less damage to commodities was shown by using $\mathrm{EF} / \mathrm{PH}_{3}$ in combination achieving high mortality of target pests (Lee et al., 2015; Yang et al., 2016). Lee et al. (2014) indicated high mortality of insect pests by a combination of $\mathrm{EF}$ and $\mathrm{PH}_{3}$ in naturally infested strawberries and cut flowers with less apparent phytotoxicity. Agarwal et al. (2015) have shown no apparent toxicity of $\mathrm{EF}$ to apple fumigation.

In the case of $\mathrm{PH}_{3}$ fumigation alone, there was no difference in celery quality or phytotoxicity observed compared with untreated celery. This is consistent with the result obtained by Liu (2008). Previous studies have shown that $\mathrm{PH}_{3}$ fumigation of vegetables is effective and safe for postharvest and commercial applications for insect control. Therefore, $\mathrm{PH}_{3}$ remains one of the best fumigants for vegetable fumigation because it causes less phytotoxicity compared with other gases (Horn et al., 2005; Lee et al., 2012; Liu, 2008). Likewise, $\mathrm{PH}_{3}$ treatments 
alone at various doses achieved high mortality on purple scum springtails and maintained commodity at high quality. The sensory evaluation of fumigated celery bunches were similar to that of untreated control. There was no negative effect on quality parameters. Several studies indicated that $\mathrm{PH}_{3}$ fumigation causes no significant effect on sensory evaluation in broccoli, tomato, and green pepper (C. annuum) (Ertürk et al., 2018; Liu, 2008).

Based on our results, treatments on purple scum springtails in celery, $\mathrm{EF}$ alone and in combination with $\mathrm{PH}_{3}$, can control the target pest of purple scum springtails; however, the combination is phytotoxic to the commodity. By contrast, $\mathrm{PH}_{3}$ alone achieved $100 \%$ kill of the target pest with no phytotoxic effect on the commodity.

Based on these findings, we conclude that $\mathrm{PH}_{3}$ has excellent potential for pre-shipping treatment of export celery for control of purple scum springtails with little or no adverse effect on celery quality.

\section{Literature cited}

Agarwal, M., Y. Ren, J. Newman, and S. Learmonth. 2015. Ethyl formate: A potential disinfestation treatment for eucalyptus weevil (Gonipterus platensis) (Coleoptera: Curculionidae) in apples. J. Econ. Entomol. 108:2566-2571.

Barrett, D.M., J.C. Beaulieu, and R. Shewfelt. 2010. Color, flavor, texture, and nutritional quality of fresh-cut fruits and vegetables: Desirable levels, instrumental and sensory measurement, and the effects of processing. Crit. Rev. Food Sci. Nutr. 50:369-389.

Berck, B. 1968. Sorption of phosphine by cereal products. J. Agr. Food Chem. 16:419-425.

Chahartaghi, M., R. Langel, S. Scheu, and L. Ruess. 2005. Feeding guides in Collembola based on nitrogen stable isotope ratios. Soil Biol. Biochem. 37:17181725.

Dhaliwal, G.S. 1975. Analysis of some important factors affecting sorption of fumigants by food commodities. J. Food Sci. Technol. 12:1-5.

Ertürk, S., F. Şen, M. Alkan, and M. Ölçülü. 2018. Effect of different phosphine gas concentrations against Frankliniella occidentalis (Thysanoptera: Thripidae) on tomato and green pepper fruit, and determination of fruit quality after application under low-temperature storage conditions. Turk. Entomol. Derg. 42:85-92.

Greenslade, P. 2007. The potential of Collembola to act as indicators of landscape stress in Australia. Austral. J. Expt. Agr. 47:424-434.

Greenslade, P. and A. Clift. 2004. Review of pest arthropods recorded from commercial mushroom farms in Australia. Australas. Mycol. 23:77-93.

Greenslade, P. and J. Ireson. 1986. Collembola of the southern Australian culture steppe and urban environments: A review of their pest status and the key to identification. Austral. J. Entomol. 25:273291.

Greenslade, P., J. Ireson, and D. Skarżyński. 2014. Biology and key to the Australian species of Hypogastrura and Ceratophysella (Collembola: Hypogastruridae). Austral. Entomol. 53:53-74.

Greenslade, P. and R.L. Kitching. 2011. Potential effects of climatic warming on the distribution of Collembola along an altitudinal transect in Lamington $\mathrm{Na}$ tional Park, Queensland, Australia. Mem. Queensl. Mus. 55:333-347.

Horn, F., P. Horn, and J. Sullivan. 2005. Current practice in fresh fruit fumigation with phosphine in Chile. Proc. Annu. Res. Conf. Methyl Bromide Alternatives and Emissions Reductions, San Diego, CA, 31 Oct. to 3 Nov. 2005. p. 31.

Horticulture Australia. 2009. Vegetable production in Western Australia. 9 Apr. 2017. <https://ausveg.com.au/ app/data/technical-insights/docs/ VegetableProductioninWesternAustralia. pdf>.

Horticulture Innovation Australia. 2017. Australian horticulture statistics handbook: Vegetables, 2015-2016. 19 Mar. 2018. <http://horticulture.com.au/wpcontent/uploads/2017/10/HorticultureStatistics-Handbook-2015-16-VegetablesNew.pdfs.

Jamieson, L.E., N.E.M. Page-Weir, A. Chhagan, D.W. Brash, D. Klementz, B.L. Bycroft, P.G. Connolly, B.C. Waddell, R. Gilbertson, F. Bollen, and A.B. Woolf. 2012. Phosphine fumigation to disinfest kiwifruit. N. Z. Plant Protection 65:3543.

Karunaratne, C., G.A. Moore, R.B. Jones, and R.F. Ryan. 1997. Vase life of some cut flowers following fumigation with phosphine. HortScience 32:900-902.

Kim, B., S. Jung, H. Park, E. Myung, M. Park, and B. Lee. 2013. Commercial scale fumigation of ethyl formate for promising export paprika and tomato in Korea. Proc. Korean Soc. Appl. Entomol. Conf.,
Hoengsong, Korea, 24-25 Oct. 2013. p. 235.

Lee, B.H., B.S. Kim, S.A. Jung, and E.J. Myung. 2013. Enhansive effect of two fumigants, ethyl formate and phosphine gas, to both control cotton aphid and two-spotted spider mite in applying export strawberries. Proc. Korean Soc. Appl. Entomol. Conf., Muju, Korea, 1-2 Apr. 2013. p. 106.

Lee, B.H., H.M. Kim, B.S. Kim, J.O. Yang, Y.M. Moon, and Y. Ren. 2015. Evaluation of the synergistic effect between ethyl formate and phosphine for control of Aphis gossypii (Homoptera: Aphididae). J. Econ. Entomol. 109:143147.

Lee, B.H., B.S. Kim, J. Tumambing, and Y.M. Moon. 2012. ECO2FUME as a quarantine fumigant for export paprika, cherry, tomato, and strawberry. Proc. 9 Intl. Conf. Controlled Atmosphere Fumigation Stored Prod., Antalya, Turkey, 15-19 Oct. 2012. p. 305-309.

Lee, B.H., B.S. Kim, J.O. Yang, C.K. Park, and Y. Ren. 2014. Evaluation of synergistic effect between ethyl formate and phosphine for control of three species Aphids in perishable commodity. Proc. 1lth Intl. Working Conf. Stored Prod. Protection. p. 979-984.

Liu, Y.B. 2008. Low temperature phosphine fumigation for postharvest control of western flower thrips (Frankliniella occidentalis) (Thysanoptera: Thripidae) on lettuce, broccoli, asparagus, and strawberry. J. Econ. Entomol. 101:17861791.

Liu, Y.B. 2009. Low temperature phosphine fumigation for postharvest pest control on fresh vegetables. Proc. Intl. Res. Conf. Methyl Bromide Alternatives Emissions Reductions, San Diego, CA, 29 Oct. to 1 Nov. 2009. p. 29.

Liu, Y.B. 2011. Oxygen enhances phosphine toxicity for postharvest pest control. J. Econ. Entomol. 104:1455-1461.

Majer, J., M.D. Sousa, and P.L. Whittle. 2014. Report on restrictions for exporting celery (Apium graveolens). 26 Dec. 2016 . <http://www.aph.gov.au/ DocumentStore ashx? $\mathrm{id}=4 \mathrm{f} 4 \mathrm{~d} 3493-0651$ 4 e 7 d-b89a-db8e2740a 8 cd \& subId = $252932>$.

Moon, Y.B. 2012. Development of optimal methods of phosphine fumigation to control insect pests on cut flowers and nursery stocks. Korea Univ., Seoul, Korea, Master's Thesis.

Popenoe, C.H. 1917. Mushroom pests and how to control them. U.S. Dept. Agr. Farmer's Bul. 789.3-16. 
Raffo, A., F. Sinesio, E. Moneta, N. Nardo, M. Peparaio, and F. Paoletti. 2006. Internal quality of fresh and cold stored celery petioles described by sensory profile, chemical and instrumental measurements. Eur. Food Res. Technol. 222:590-599.

Reddy, P.V., Y. Rajashekar, K. Begum, B. Chandrappa Leelaja, and S. Rajendran. 2007. The relation between phosphine sorption and terminal gas concentrations in successful fumigation of food commodities. Pest Mgt. Sci. 63:96-103.

Ren, Y., B. Lee, and B. Padovan. 2011. Penetration of methyl bromide, sulfuryl fluoride, ethanedinitrile and phosphine into timber blocks and the sorption rate of the fumigants. J. Stored Prod. Res. 47:63-68.

Ren, Y. and D. Mahon. 2006. Fumigation trials on the application of ethyl formate to wheat, split faba beans and sorghum in small metal bins. J. Stored Prod. Res. 42:277-289.

Ren, Y., D. Mahon, J. van Someren Graver, and M. Head. 2008. Fumigation trial on direct application of liquid carbonyl sulphide to wheat in a $2500 \mathrm{t}$ concrete silo. J. Stored Prod. Res. 44:115125.

Simpson, T., V. Bikoba, and E.J. Mitcham. 2004. Effects of ethyl formate on fruit quality and target pest mortality for harvested strawberries. Postharvest Biol. Technol. 34:313-319.

Stewart, J. and Y. Aharoni. 1983. Vacuum fumigation with ethyl formate to control the green peach aphid (Myzus persicae) in packaged head lettuce. J. Amer. Soc. Hort. Sci. 108:295-298.

Tarr, C., R. Reuss, P. Clingeleffer, and P. Annis. 2007. The use of ethyl formate for space fumigation of dried vine fruit. Proc. Intl. Conf. Controlled Atmosphere Fumigation Stored Prod, Gold Coast, Australia, 8-13 Aug. 2007. p. 193-205.

Van Epenhuijsen, C., D. Hedderley, K. Somerfield, and D. Brash. 2007. Efficacy of ethyl formate and ethyl acetate for the control of onion thrips (Thrips tabaci). N. Z. J. Crop Hort. Sci. 35:267-274.
Weller, G.L. and J.E. Graver. 1998. Cut flower disinfestations: Assessment of replacement fumigants for methyl bromide. Postharvest Biol. Technol. 14:325333.

Williams, P., G. Hepworth, F. Goubran, M. Muhunthan, and K. Dunn. 2000. Phosphine as a replacement for methyl bromide for postharvest disinfestation of citrus. Postharvest Biol. Technol. 19:193-199.

Yang, J., Y. Park, I.H. Hyun, G.H. Kim, B.S. Kim, B.H. Lee, and Y. Ren. 2016. A combination treatment using ethyl formate and phosphine to control Planococcus citri (Hemiptera: Pseudococcidae) on pineapples. J. Econ. Entomol. 109: 2355-2363.

Yommi, A.K., N.M. Di Gerónimo, L.E. Carrozzi, V. Quillehauquy, M.G. Goñi, and S.I. Roura. 2013. Morphological, physicochemical and sensory evaluation of celery harvested from early to late maturity. Hort. Bras. 31:236-241.

Zhang, Z. and C.W. Van Epenhuijsen. 2004. Improved envirosol fumigation methods for disinfesting export cut flowers and foliage crops. N.Z. Inst. Crop Food Res., Palmerston North, New Zealand. 